\title{
QUATERNARY GLACIAL CYCLES: KARST PROCESSES AND THE GLOBAL $\mathrm{CO}_{2}$ BUDGET
}

\author{
KVARTARNE POLEDENITVE: KRAŠKI PROCESI \\ IN GLOBALNA BILANCA $\mathrm{CO}_{2}$
}

\author{
Erik B. LARSON ${ }^{1} \&$ John E. MYLROIE ${ }^{2}$
}

\begin{abstract}
UDC 551.435.8:546.264-31

546.264-31:551.79

Erik B. Larson \& John E. Mylroie: Quaternary glacial cycles: Karst processes and the global $\mathrm{CO}_{2}$ budget

Extensive research has been conducted investigating the relationship between karst processes, carbonate deposition and the global carbon cycle. However, little work has been done looking into the relationship between glaciations, subsequent sea level changes, and aerially exposed land masses in relation to karstic processes and the global carbon budget. During glaciations sea-level exposed the world's carbonate platforms. With the sub-aerial exposure of the platforms, karst processes can occur, and the dissolution of carbonate material can commence, resulting in the drawdown of $\mathrm{CO}_{2}$ from the atmosphere as $\mathrm{HCO}_{3}^{-}$. Furthermore, the material on the platform surfaces is primarily aragonite which is more readily soluble than calcite allowing karst processes to occur more quickly. During glaciations arctic carbonates and some of the temperate carbonates are blanketed in ice, effectively removing those areas from karst processes. Given the higher solubility of aragonite, and the extent of carbonate platforms exposed during glaciations, this dissolution balances the $\mathrm{CO}_{2}$ no longer taken up by karst processes at higher latitudes that were covered during the last glacial maximum The balance is within $0.001 \mathrm{GtC} / \mathrm{yr}$, using soil $p \mathrm{CO}_{2}\left(0.005 \mathrm{GtC} / \mathrm{yr}\right.$ assuming atmospheric $\left.p \mathrm{CO}_{2}\right)$ which is a difference of $<1 \%$ of the total amount of atmospheric $\mathrm{CO}_{2}$ removed in a year by karst processes. Denudation was calculated using the maximum potential dissolution formulas of Gombert (2002). On a year to year basis the net amount of atmospheric carbon removed through karstic processes is equivalent between the last glacial maximum and the present day, however, the earth has spent more time in a glacial configuration during the Quaternary, which suggests that there is a net drawdown of atmospheric carbon during glaciations from karst processes, which may serve as a feedback to prolong glacial episodes. This research has significance for understanding the global carbon budget during the Quaternary.

Keywords: Karst, Global Carbon Budget, Quaternary, Last
\end{abstract} Glacial Maximum, Carbonate Dissolution.
Izvleček

UDK 551.435.8:546.264-31

546.264-31:551.79

Erik B. Larson \& John E. Mylroie: Kvartarne poledenitve: kraški procesi in globalna bilanca $\mathrm{CO}_{2}$

$\mathrm{O}$ pomenu kraških procesov $\mathrm{v}$ globalni bilanci ogljika je bilo narejenih veliko število raziskav, le malo pa jih govori o povezavi med poledenitvami ter $\mathrm{z}$ njimi povezanimi spremembami morske gladine in izpostavljenost kraškega površja zakrasevanju. Med poledenitvami je zaradi padca morske gladine večina karbonatnih platform izpostavljenih meteornemu zakrasevanju. Preko raztapljanja se $\mathrm{CO}_{2}$ iz zraka pretvarja v bikarbonat $\mathrm{v}$ raztopini. Karbonatne platforme so grajene pretežno it aragonita, ki je bolj topen od kalcita, kar še dodatno prispeva $\mathrm{k}$ omenjeni pretvorbi. Po drugi strani pa so med poledenitvami karbonati $\mathrm{v}$ arktičnih in $\mathrm{v}$ nekaterih zmernih klimatskih pasovih pokriti z ledom in na ta način izključeni iz procesov zakrasevanja. Po naših ocenah se učinek obeh mehanizmov izniči v okviru nekaj tisočink gigatone ogljika letno, kar je manj kot $1 \%$ celotnega atmosferskega $\mathrm{CO}_{2}$, ki ga sicer odstranijo kraški procesi. Na letni bazi je torej količina atmosferskega ogljika, ki ga odstranijo kraški procesi danes, enaka kot v obdobju poledenitvenega viška. Po drugi strani pa je večji delež kvartarja pripadal poledenitvam. Raziskava ima pomen za razumevanje globalnega ravnotežja ogljika v kvartarju.

Ključne besede: Kras, globalna bilanca ogljika, kvartar, zadnji poldedenitveni maximum, raztapljanje karbonatov.

\footnotetext{
${ }^{1}$ Department of Geosciences, Mississippi State University, Mississippi State, MS 39762-5448, e-mail: ebl47@msstate.edu, ${ }^{2}$ Department of Geosciences, Mississippi State University, Mississippi State, MS 39762-5448, e-mail: mylroie@geosci.msstate.edu, Received/Prejeto: 19.1.2013
} 


\section{INTRODUCTION}

Karst processes have long been known to result in the drawdown of atmospheric $\mathrm{CO}_{2}$ (e.g. Ford \& Williams 2007; White 1988). The process results in the sequestration of one molecule of $\mathrm{CO}_{2}$ for each molecule of calcium carbonate dissolved (equation 1).

$\mathrm{CaCO}_{3}+\mathrm{CO}_{2}+\mathrm{H}_{2} \mathrm{O} \leftrightarrow \mathrm{Ca}^{2+}+2 \mathrm{HCO}_{3}^{-} \quad$ (Equation 1)

This process has been proposed to result in significant removal of atmospheric $\mathrm{CO}_{2}$ (e.g. Gombert 2002; Liu et al. 2011; Mylroie 1993; 2008). Gombert (2002) proposed that on the global scale karst denudation resulted in the removal of $0.3 \mathrm{Gt}$ of $\mathrm{C}$ per year from the atmosphere. This $0.3 \mathrm{Gt} \mathrm{C}$ per year represents $21 \%$ of the unknown carbon sink in the continental biosphere suggesting that karst processes play a significant role in balancing the global carbon budget (Gombert 2002; Liu et al. 2011; Schimel et al. 1996).
The goal of this study is to determine the amount of carbon that is removed from the atmosphere during karst dissolution on a global scale for the present day and during the last glacial maximum (LGM) and to determine if the amount of carbon withdrawn during these two time periods balances out. The only other study to examine this issue looked only at a local scale in the Bahamas (Mylroie 1993). Mylroie (1993) discovered that the sequestration of carbon during the LGM by carbonate dissolution and release of carbon during the present day from carbonate deposition resulted in a net balance when viewed over the average length of glacial and interglacial cycles.

The material presented below represents the continuation of Mylroie's (1993) efforts applied to a global scale.

\section{METHODS}

Karst denudation was modeled using Gombert's (2002) maximal potential denudation model that is based on White's (1984; 1988) maximum dissolution model. Gombert's (2002) model is a climatic model which requires as inputs only effective precipitation, $p \mathrm{CO}_{2}$, temperature to correct the equilibrium constants and karstic area. Gombert's (2002) model was applied to the different Köppen climate zones in an effort to model global karst denudation more accurately.

The Köppen climatic zones used were: polar, cold, cold temperate, warm temperate, Mediterranean, desert, subtropical, wet tropical and equatorial as suggested by Gombert (2002).

Effective precipitation in the modern day was calculated using the precipitation data of Miller (1949) and evapotranspiration data from $\mathrm{Mu}$ et al. (2011). Effective precipitation during the LGM was calculated using rainfall data from Miller (1949), which was corrected for the LGM as suggested by Clark et al. (1999), and evapotranspiration data were derived from Bush \& Philander (1999).

$p \mathrm{CO}_{2}$ data were calculated using Brooks' (1983) model for soil $p \mathrm{CO}_{2}$ using effective precipitation. Atmospheric $p \mathrm{CO}_{2}$ was also used to provide an end member condition that would be similar to no soil cover at all (Palmer 2007).

Equilibrium constants for calcite and aragonite in the present day were corrected for temperature using
Miller's (1949) temperature data. The equilibrium constants used came from Plummer and Busenberg (1982). The equilibrium constants used during the LGM were modified using Clark et al.s (2009) temperature correction.

Karstic area was calculated using Ford and Williams' (2007) global karst map; the Köppen climatic zones were overlaid on this resulting in karst areas for the different climate zones. During the glaciations when sea-level dropped, the carbonate platforms and coral reefs around the world would have become sub-aerially exposed resulting in an increase in karstic areas of 1.25 million $\mathrm{km}^{2}$ (Smith 1978). These newly gained areas were then placed into their respective climatic zones. These new areas were treated to be aragonite instead of calcite (as all other areas were treated) as the sediments in the coral reefs and on the carbonate platforms are predominately aragonite (Reijmer et al. 2009).

As a result of glaciations several high latitude and high altitude karst areas were covered with glaciers effectively removing them from karstic processes. A total of 4.7 million $\mathrm{km}^{2}$ of karst area was removed from the global karst areas and each subset was then subtracted from their respective climatic zones (Clark \& Mix 2002; Velichko et al. 1997).

With all these parameters now defined, Gombert's (2002) maximal potential dissolution model was applied 
to the different climatic zones. The model was run using either atmospheric or soil $p \mathrm{CO}_{2}$ and either assuming all the carbonate material was calcite or that some of the newly exposed carbonate areas during the LGM were aragonite, resulting in four model runs. These models and the assumptions within them can cause significant spread in the final denudation rates. White (2007) re- ports that karst denudation rates in the present can vary over an order of magnitude within a geographic area. However, when viewed over a large scale these deviations should cancel out, and as long as there is consistency in the calculations these errors should cancel out between the present and the LGM resulting in a net difference that is precise.

\section{RESULTS}

Denudation rates in the different climatic zones were determined to vary from $10 \mathrm{~mm}$ per thousand years, up to $100 \mathrm{~mm}$ per thousand years depending on the $\mathrm{pCO}_{2}$ and climatic conditions. The extrapolation of these denudation rates to volume of carbon drawn from the atmosphere, assuming soil $p \mathrm{CO}_{2}$ and all calcite mineralogy, can be found in Tab. 1. The volume of carbon re-

Tab. 1: The calculated maximal potential dissolution of karst processes around the world. These data were created using soil $\mathrm{pCO}_{2}$ and assuming all the $\mathrm{CaCO}_{3}$ was calcite.

\begin{tabular}{l|r|r|r}
\hline & Present Day & LGM & Difference \\
\hline Polar & $2.80 \mathrm{E}+10$ & $7.86 \mathrm{E}+09$ & $2.01 \mathrm{E}+10$ \\
\hline Cold & $5.58 \mathrm{E}+10$ & $5.33 \mathrm{E}+10$ & $2.49 \mathrm{E}+09$ \\
\hline Cold Temperate & $2.42 \mathrm{E}+11$ & $1.98 \mathrm{E}+11$ & $4.45 \mathrm{E}+10$ \\
\hline Warm Temperate & $1.26 \mathrm{E}+11$ & $1.36 \mathrm{E}+11$ & $-9.65 \mathrm{E}+09$ \\
\hline Mediterranean & $3.46 \mathrm{E}+10$ & $3.79 \mathrm{E}+10$ & $-3.26 \mathrm{E}+09$ \\
\hline Desertic & $1.31 \mathrm{E}+09$ & $2.57 \mathrm{E}+09$ & $-1.26 \mathrm{E}+09$ \\
\hline Subtropical & $1.39 \mathrm{E}+10$ & $2.35 \mathrm{E}+10$ & $-9.58 \mathrm{E}+09$ \\
\hline Wet Tropical & $1.73 \mathrm{E}+11$ & $2.04 \mathrm{E}+11$ & $-3.14 \mathrm{E}+10$ \\
\hline Equitorial & $6.43 \mathrm{E}+10$ & $6.60 \mathrm{E}+10$ & $-1.72 \mathrm{E}+09$ \\
\hline Total (m ${ }^{3 / 1000 y r) ~}$ & $7.40 \mathrm{E}+11$ & $7.29 \mathrm{E}+11$ & $1.03 \mathrm{E}+10$ \\
\hline Total (GtC / yr) & 0.222 & 0.219 & 0.003 \\
\hline
\end{tabular}

moved from the atmosphere assuming soil $\mathrm{pCO}_{2}$ and both calcite and aragonite mineralogy can be found in Tab. 2. The volume of carbon taken out of the atmosphere assuming atmospheric $p \mathrm{CO}_{2}$ and only calcite can be found in Tab. 3. Finally, the volume of carbon drawn from the atmosphere assuming atmospheric $\mathrm{pCO}_{2}$ and calcite and aragonite mineralogy can be found in Tab. 4 . A summary table of all the different volumes of carbon removed can be found in Tab. 5 .

In summary about $0.21 \mathrm{Gt} C$ per year are withdrawn under all the various karst dissolution models, for both the present day and the last glacial maximum. In
Tab. 2: The calculated maximal potential dissolution of karst processes around the world. These data were created using soil $p \mathrm{CO}_{2}$ and assuming that the currently exposed $\mathrm{CaCO}_{3}$ is calcite, but the coral reefs and carbonate platforms are covered with aragonite sediment.

\begin{tabular}{l|r|r|r}
\hline & Present Day & LGM & Difference \\
\hline Polar & $2.80 \mathrm{E}+10$ & $7.86 \mathrm{E}+09$ & $2.01 \mathrm{E}+10$ \\
\hline Cold & $5.58 \mathrm{E}+10$ & $5.33 \mathrm{E}+10$ & $2.49 \mathrm{E}+09$ \\
\hline Cold Temperate & $2.42 \mathrm{E}+11$ & $1.98 \mathrm{E}+11$ & $4.45 \mathrm{E}+10$ \\
\hline Warm Temperate & $1.26 \mathrm{E}+11$ & $1.36 \mathrm{E}+11$ & $-9.65 \mathrm{E}+09$ \\
\hline Mediterranean & $3.46 \mathrm{E}+10$ & $3.79 \mathrm{E}+10$ & $-3.28 \mathrm{E}+09$ \\
\hline Desertic & $1.31 \mathrm{E}+09$ & $2.57 \mathrm{E}+09$ & $-1.26 \mathrm{E}+09$ \\
\hline Subtropical & $1.39 \mathrm{E}+10$ & $2.38 \mathrm{E}+10$ & $-9.90 \mathrm{E}+09$ \\
\hline Wet Tropical & $1.73 \mathrm{E}+11$ & $2.19 \mathrm{E}+11$ & $-4.62 \mathrm{E}+10$ \\
\hline Equitorial & $6.43 \mathrm{E}+10$ & $6.60 \mathrm{E}+10$ & $-1.72 \mathrm{E}+09$ \\
\hline Total (m $\left.{ }^{3} / 1000 y r\right)$ & $7.40 \mathrm{E}+11$ & $7.44 \mathrm{E}+11$ & $-4.82 \mathrm{E}+09$ \\
\hline Total (GtC / yr) & 0.222 & 0.223 & -0.001 \\
\hline
\end{tabular}

Tab. 3: The calculated maximal potential dissolution of karst processes around the world. These data were created using atmospheric $\mathrm{pCO}_{2}$ and assuming all the $\mathrm{CaCO}_{3}$ was calcite.

\begin{tabular}{l|r|r|r}
\hline & Present Day & LGM & Difference \\
\hline Polar & $4.43 \mathrm{E}+10$ & $1.24 \mathrm{E}+10$ & $3.18 \mathrm{E}+10$ \\
\hline Cold & $7.25 \mathrm{E}+10$ & $6.93 \mathrm{E}+10$ & $3.23 \mathrm{E}+09$ \\
\hline Cold Temperate & $2.19 \mathrm{E}+11$ & $1.78 \mathrm{E}+11$ & $4.02 \mathrm{E}+10$ \\
\hline Warm Temperate & $1.39 \mathrm{E}+11$ & $1.50 \mathrm{E}+11$ & $-1.06 \mathrm{E}+10$ \\
\hline Mediterranean & $4.13 \mathrm{E}+10$ & $4.51 \mathrm{E}+10$ & $-3.88 \mathrm{E}+09$ \\
\hline Desertic & $2.32 \mathrm{E}+09$ & $4.80 \mathrm{E}+09$ & $-2.48 \mathrm{E}+09$ \\
\hline Subtropical & $8.98 \mathrm{E}+09$ & $1.55 \mathrm{E}+10$ & $-6.57 \mathrm{E}+09$ \\
\hline Wet Tropical & $1.28 \mathrm{E}+11$ & $1.60 \mathrm{E}+11$ & $-3.20 \mathrm{E}+10$ \\
\hline Equitorial & $3.55 \mathrm{E}+10$ & $3.56 \mathrm{E}+10$ & $-8.92 \mathrm{E}+07$ \\
\hline Total (m $\left.{ }^{3} / 1000 \mathrm{yr}\right)$ & $6.91 \mathrm{E}+11$ & $6.71 \mathrm{E}+11$ & $1.96 \mathrm{E}+10$ \\
\hline Total (GtC/ yr) & 0.207 & 0.201 & 0.006 \\
\hline
\end{tabular}


Tab. 4: The calculated maximal potential dissolution of karst processes around the world. These data were created using atmospheric $\mathrm{pCO}_{2}$ and assuming that the currently exposed $\mathrm{CaCO}_{3}$ is calcite, but the coral reefs and carbonate platforms are covered with aragonite sediment.

\begin{tabular}{l|r|r|r}
\hline & Present Day & LGM & Difference \\
\hline Polar & $4.43 \mathrm{E}+10$ & $1.24 \mathrm{E}+10$ & $3.18 \mathrm{E}+10$ \\
\hline Cold & $7.25 \mathrm{E}+10$ & $6.93 \mathrm{E}+10$ & $3.23 \mathrm{E}+09$ \\
\hline Cold Temperate & $2.19 \mathrm{E}+11$ & $1.78 \mathrm{E}+11$ & $4.02 \mathrm{E}+10$ \\
\hline Warm Temperate & $1.39 \mathrm{E}+11$ & $1.50 \mathrm{E}+11$ & $-1.06 \mathrm{E}+10$ \\
\hline Mediterranean & $4.13 \mathrm{E}+10$ & $4.52 \mathrm{E}+10$ & $-3.91 \mathrm{E}+09$ \\
\hline Desertic & $2.32 \mathrm{E}+09$ & $4.80 \mathrm{E}+09$ & $-2.48 \mathrm{E}+09$ \\
\hline Subtropical & $8.98 \mathrm{E}+09$ & $1.58 \mathrm{E}+10$ & $-6.78 \mathrm{E}+09$ \\
\hline Wet Tropical & $1.28 \mathrm{E}+11$ & $1.63 \mathrm{E}+11$ & $-3.44 \mathrm{E}+10$ \\
\hline Equitorial & $3.55 \mathrm{E}+10$ & $3.56 \mathrm{E}+10$ & $-8.92 \mathrm{E}+07$ \\
\hline Total (m ${ }^{3 / 1000 y r)}$ & $6.91 \mathrm{E}+11$ & $6.74 \mathrm{E}+11$ & $1.70 \mathrm{E}+10$ \\
\hline Total (GtC/yr) & $\mathbf{0 . 2 0 7}$ & $\mathbf{0 . 2 0 2}$ & $\mathbf{0 . 0 0 5}$ \\
\hline
\end{tabular}

Tab. 5: The summary data from tables 1-4.

\begin{tabular}{|c|c|c|c|}
\hline \multirow[b]{2}{*}{ Scenario } & \multicolumn{3}{|c|}{$\mathrm{GtC} / \mathrm{yr}$} \\
\hline & Present Day & LGM & Difference \\
\hline Soil $\mathrm{pCO}_{2}-$ Calcite & \multirow[b]{2}{*}{0.222} & 0.219 & 0.003 \\
\hline $\begin{array}{l}\text { Soil } \mathrm{pCO}_{2}-\text { Calcite \& } \\
\text { Aragonite }\end{array}$ & & 0.223 & -0.001 \\
\hline $\begin{array}{l}\text { Atmospheric } \mathrm{pCO}_{2}- \\
\text { Calcite }\end{array}$ & \multirow{2}{*}{0.207} & 0.201 & 0.006 \\
\hline $\begin{array}{l}\text { Atmospheric } \mathrm{pCO}_{2}- \\
\text { Calcite \& Aragonite }\end{array}$ & & 0.202 & 0.005 \\
\hline
\end{tabular}

most cases the amount of carbon withdrawn from the atmosphere during the LGM is slightly less than that in the present day, but the difference is less than $1 \%$.

\section{DISCUSSION:}

The total $0.21 \mathrm{Gt} C$ per year that are removed from the atmosphere by karst processes in the modern day correlates well within the $0.11-0.47 \mathrm{Gt} C$ per year that have been calculated by previous workers (e.g. Gombert 2002; Liu et al. 2011). Given that the current data matches well with previous work, some of which used different methods, provides confidence for the rest of the data and the conclusions regarding the LGM. The amount of carbon removed from the atmosphere may not actually be sequestered; the carbon as $\mathrm{CO}_{2}$ could degas from surface water bodies back to the atmosphere, or be deposited as tufas (Equation 1) before even reaching the oceans where the carbon could be deposited as carbonates.

\section{THE LAST GLACIAL MAXIMUM}

The amount of carbon withdrawn from the atmosphere during the present day and during the LGM is essentially equal, at about $0.21 \mathrm{Gt} C$ per year (Tab. 5). During the LGM sea-level was about 125 meters lower than today resulting in the sub-aerial exposure of coral reefs and carbonate platforms, while covering up high latitude and high altitude areas with glaciers. Some carbonate platforms, such as the Bahamas, become exposed with a sealevel fall of only $20 \mathrm{~m}$; almost all carbonate platforms are exposed by a sea-level fall of $60 \mathrm{~m}$. Given that the amount of carbon removed from the atmosphere through karst processes balances between these two times with signifi- cant geographic changes implies that land area fluctuations, in conjunction with modified climate are sufficient to make up for the glacial impacts. Taking into account the mineralogy changes helps to account for some of the difference between the present day and the LGM, but it has relatively insignificant control in the total carbon volume calculations (Tab. 5).

During the cycling from glacial to non-glacial periods there would be regional variation in the amount of karst denudation (and subsequent draw down of atmospheric carbon) as White (2007) demonstrated, occurs during the present day. This variation is in part due to the heterogeneous nature of the rocks, the $\mathrm{pCO}_{2}$, and precipitation conditions. However, if the same assumptions are made in the calculations for karst denudation in the present and during the LGM these errors should effectively cancel out, and the net difference (or lack of difference in the case of this study) becomes significant in demonstrating the net amount of carbon removed from the atmosphere during the present and LGM are equivalent.

During the Quaternary, glacial periods have lasted about 10 times longer than the interglacial periods (e.g. Mylroie 1993). This is significant because when looked at over the entire Quaternary it becomes obvious that there would be a net removal of atmospheric carbon due to dissolution processes occurring from carbonate platform exposure. This may result in a feedback mechanism re- 
sulting in the prolonging of glacial periods, as proposed by Mylroie (1993).

Throughout this research the deposition of carbonates has been ignored from the net balance, but now it will be addressed. During LGM the sea-level drop would cause the carbonate factory to become sub-aerially exposed; the shutdown of the carbonate factory would prevent the deposition of significant carbonate sediments and prevent the release of that $\mathrm{CO}_{2}$ into the atmosphere (Equation 1). At the present day the carbonate factory is actively releasing $\mathrm{CO}_{2}$ into the atmosphere, and based on this qualitative statement there should be a net sequestration of carbon during glacial periods and a net release of carbon during interglacial periods caused by karst processes. For the Bahama platform, Mylroie $(1993 ; 2008)$ demonstrated that the carbon flux through a glacial-interglacial cycle was equal. The rapid release of $\mathrm{CO}_{2}$ by carbonate deposition during a $\sim 10 \mathrm{ka}$ interglacial was compensated almost exactly by the ten times slower $\mathrm{CO}_{2}$ sequestration during the $\sim 100 \mathrm{ka}$ of glacioeustatic platform exposure. This loss of atmospheric $\mathrm{CO}_{2}$ due to global processes (e.g. primary productivity) including karstic processes during the Quaternary is documented in the Vostok ice core by higher atmospheric $\mathrm{CO}_{2}$ during interglacial periods and lower atmospheric $\mathrm{CO}_{2}$ during glacial periods (e.g. Falkowski et al. 2000; Petit et al. 1998).

\section{CONCLUSIONS}

Given the maximal potential denudation formula of Gombert (2002) the global carbon budget was calculated with respect to karst dissolution for both the present day and the LGM. Karstic processes result in the removal of atmospheric carbon through dissolution (equation 1). Both the present day and LGM were found to remove 0.21 Gt C per year from the atmosphere, within $1 \%$ of each other regardless of the model used. This represents $16 \%$ of the unknown carbon sink of the continental biosphere (Schimel et al. 1996). Furthermore, this research demonstrates that through land area changes, climatic changes and mineralogy differences the amount of carbon removed through karstic dissolution processes in the present is equivalent to the amount removed from the atmosphere during the LGM. What is different, given the steep-sided nature of most carbonate platforms, is that carbonate deposition is greater during an interglacial than during a glacial cycle, perhaps compensated for by the longer duration of glacial cycles compared to interglacial conditions. Furthermore, the yearly balance between today's atmospheric carbon removal by karst processes and the LGM's carbon drawdown by karst processes indicates the importance of climate in karst dissolution. The loss of 4.7 million $\mathrm{km}^{2}$ of karst area in high latitude and high altitude regions to ice cover during a glaciation is exactly compensated by the gain of 1.25 million $\mathrm{km}^{2}$ of karst area in tropical and subtropical regions due to sea level fall. Finally, this research is significant as it is the first to quantify the effect the Quaternary glaciations had on karstic processes with respect to atmospheric carbon removal.

\section{ACKNOWLEDGMENTS}

The authors wish to thank Will White and an anonymous reviewer for comments that improved the paper. Discussion with Philippe Gombert was useful in developing the project. Finally, the Department of Geosciences at Mississippi State University is thanked for financial support. 


\section{REFERENCES}

Brooks, G.A., Folkoff, M.E. \& E.O. Box, 1983: A world model of soil carbon dioxide.- Earth Surface Processes and Landforms, 8, 79-88.

Bush, A.B.G. \& S.G.H. Philander, 1999: The climate of the last glacial maximum: results from a coupled atmosphere-ocean general circulation model.- Journal of Geophysical Research, 104, D20, 24509-24525.

Clark, P.U. \& A.C. Mix, 2002: Ice sheets and sea level of the last glacial maximum.- Quaternary Science Reviews, 21, 1-7.

Clark, P.U., Alley, R.B. \& D. Pollard, 1999: Northern hemisphere ice-sheet influences on global climate change.- Science, 286, 1104-1111.

Clark, P.U., Dyke, A.S., Shakun, J.D., Carlson, A.E., Clark, J., Wohlfarth, B., Mitrovica, J.X., Hostetler, S.W. \& A.M. McCabe, 2009: The last glacial maximum.- Nature, 325, 710-714.

Falkowski, P., Scholes, R.J., Boyle, E., Canadell, J., Canfield, D., Elser, J., Gruber, N., Hibbard, K., Högberg, P., Linder, S., Mackenzie, F.T., Moore III, B., Pedersen, T., Rosenthal, Y., Seitzinger, S., Smetacek, V. \& W. Steffen, 2000: The global carbon cycle: a test of our knowledge of Earth as a system.- Science, 290, 291-296.

Ford, D. \& P. Williams, 2007: Karst hydrogeology and geomorphology.- Wiley, pp. 562, West Sussex.

Gombert, P., 2002: Role of karstic dissolution in global carbon cycle.- Global and Planetary Change, 33, 177-184.

Liu, Z., Dreybrodt, W. \& H. Liu, 2011: Atmospheric $\mathrm{CO}_{2}$ sink: silicate weathering or carbonate weathering?.Applied Geochemistry, 26, S292-S294.

Miller, A.A., 1949: Climatology.- Methuen and Company, pp. 325, London.

Mu, Q., Zhao, M. \& S.W. Running, 2011: Improvements to a MODIS global terrestrial evapotranspiration algorithm.- Remote Sensing of Environment, 115, 1781-1800.

Mylroie, J.E., 1993, Carbonate deposition/dissolution cycles and carbon dioxide flux in the Pleistocene.- In: White, B. (ed.) Proceedings of the sixth symposium of the geology of the Bahamas, $11^{\text {th }}-15^{\text {th }}$ June 1992, San Salvador, Bahamas, Bahamian Field Station, 103-107, Port Charlotte.

Mylroie, J.E., 2008: Late Quaternary sea-level position: evidence from Bahamian carbonate deposition and dissolution cycles.- Quaternary International, 183, 61-75.

Palmer, A.N., 2007: Cave geology.- Cave Books, pp. 454, Dayton.
Petit, J.R., Jouzel, J., Raynaud, D., Barkov, N.I., Barnola, J.M., Basile, I., Bender, M., Chappellaz, J., Davis, M., Delaygue, G., Delmotte, M., Kotlyakov, V.M., Legrand, M., Lipenkov, V.Y., Lorius, C., Pépin, L., Ritz, C., Saltzman, E. \& M. Stienenard, 1998: Climate and atmospheric history of the past 420,000 years from the Vostok ice core, Antarctica.- Nature, 399, 429-436.

Plummer, L.N. \& E. Busenberg, 1982: The solubilities of calcite, aragonite and vaterite in $\mathrm{CO}_{2}-\mathrm{H}_{2} \mathrm{O}$ solutions between 0 and $90^{\circ} \mathrm{C}$, and an evaluation of the aqueous model for the system $\mathrm{CaCO}_{3}-\mathrm{CO}_{2}-\mathrm{H}_{2} \mathrm{O}$.- Geochimica et Cosmochimica Acta, 46, 1011-1040.

Reijmer, J.J.G., Swart, P.K., Bauch, T., Otto, R., Reuning, L., Roth, S. \& S. Zechel, 2009: A re-evaluation of facies on Great Bahama Bank I: new facies maps of western Great Bahama Bank.- In: Swart, P.K., et al. (eds.) Perspectives in carbonate geology: a tribute to the career of Robert Nathan Ginsburg. Blackwell, pp. 29-246, West Sussex.

Schimel, D., Alves, D., Enting, I., Heimann, M., Joos, F., Raynaud, D., Wigley, T., Prather, M., Derwent, R., Ehhalt, D., Fraser, P., Sanhueza, E., Zhou, X., Jonas, P., Charlson, R., Rodhe, H., Sadasivan, S., Shine, K.P., Fouquart, Y., Ramaswamy, V., Solomon, S., Srinivasan, J., Albritton, D., Derwent, R., Isaksen, I., Lal, M. \& D. Wuebbles, 1996: Radiative forcing of climate change.- In: Houghton, J.T., et al. (eds.), Climate Change 1995. The Science of Climate Change. Contribution of Working Group I to the Second Assessment Report of the Intergovernmental Panel on Climate Change. Cambridge University Press, pp. 69-131, Cambridge.

Smith, S.V., 1978: Coral reef area and the contributions of reefs to processes and resources of the world's oceans.- Nature, 273, 225-226.

Velichko, A.A., Kononov, Y.M. \& M.A. Faustova, 1997: The last glaciation of earth: size and volume of icesheets.- Quaternary International, 41/42, 43-51.

White, W.B., 1984: Rate processes: chemical kinetics and karst landform development.- In: LaFleur, R.G. (ed.) Groundwater as a geomorphic agent. AllenUnwin, pp. 227-248, Boston.

White, W.B., 1988: Geomorphology and hydrology of karst terrains.- Oxford University Press, pp. 464, New York.

White, W.B., 2007: Evolution and age relations of karst landscapses.- Acta Carsologica, 36, 45-52. 